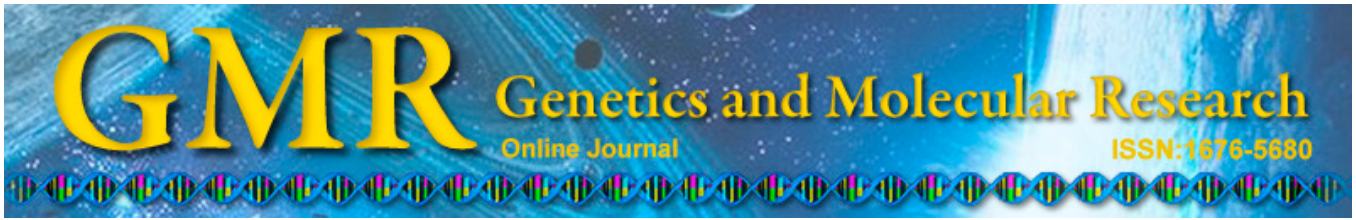

\title{
Physical wounding and ethylene stimulated embryogenic stem cell proliferation and plantlet regeneration in protocorm-like bodies of Phalaenopsis orchids
}

\author{
Y.-W. Huang', Y.-J. Tsai ${ }^{2}$, T.-C. Cheng ${ }^{2}$, J.-J. Chen ${ }^{3}$ and F.-C. Chen ${ }^{1,2}$ \\ ${ }^{1}$ Graduate Institute of Plant Science, \\ National Pingtung University of Science and Technology, Pingtung, Taiwan \\ ${ }^{2}$ Department of Plant Industry, \\ National Pingtung University of Science and Technology, Pingtung, Taiwan \\ ${ }^{3}$ Taiwan Agricultural Research Institute, Wu-Feng, Taichung, Taiwan \\ Corresponding author: F.-C. Chen \\ E-mail: fchen@mail.npust.edu.tw
}

Genet. Mol. Res. 13 (4): 9543-9557 (2014)

Received October 17, 2013

Accepted May 13, 2014

Published November 12, 2014

DOI http://dx.doi.org/10.4238/2014.November.12.3

\begin{abstract}
Phalaenopsis orchids have been regenerated by inducing protocorm-like bodies (PLBs) from etiolated leaf sections. However, the physiological and molecular mechanisms of secondary PLB development and subsequent proliferation have not been explored. Bisectionally cutting primary PLBs resulted in more secondary PLBs at 5 weeks, suggesting an embryogenic stem cell property imposed by wounding of primary PLB tissues. The ethylene precursors ethephon and 1-aminocyclopropanecarboxylic acid and the ethylene perception inhibitor silver nitrate increased PLB formation, while aminoethoxyvinylglycine decreased PLB formation. Ethylene content in wounded PLB explants increased over culture time in media containing ethylene precursors or inhibitors. mRNA levels of PhACS2, PhACS3, and $P h A C O$ were increased by ethephon and decreased by ethylene
\end{abstract}


inhibitors. Expression of genes in the ethylene signaling pathway was enhanced following ethylene-precursor treatment and was mitigated by ethylene inhibitors during PLB proliferation. Transcription of PhETR and PhEIN3, as well as PhERS, PhCTR, and PhGTP, was significantly increased $12 \mathrm{~h}$ after ethylene treatment. Ethylene and physical wounding stimulated secondary PLB formation in Phalaenopsis, probably through ethylene biosynthesis and signal transduction.

Key words: 1-Aminocyclopropanecarboxylic acid; Phalaenopsis; 2-Chloroethylphosphonic acid (ethephon); Silver nitrate;

Aminoethoxyvinylglycine; Embryogenic stem cells

\section{INTRODUCTION}

Potted plants of Phalaenopsis, including cultivars of Phalaenopsis and Doritaenopsis, its intergeneric hybrid with Doritis, are among the orchids showing the highest demand in global markets because of their showy and long-lasting flowers. To meet the demand for a large supply of young plants, an efficient micropropagation system is required. Several tissues have been used for in vitro culture, including flower-stalk nodes and internodes (Lin et al., 2000), cut ends of stems (Chen and Chang, 2000), protocorm-like body (PLB) sections (Young et al., 2000), leaves (Park et al., 2002), and shoot tips (Tokuhara and Mii, 2001).

Amaki and Higuchi (1989) reported that long-term culture of segments from the basal part of PLBs produced a large number of secondary PLBs. However, the spectrum of PLB proliferation and the mode of their formation in repeated subcultures has not been investigated (Amaki and Higuchi, 1989). Induction of PLBs from leaf sections by direct somatic embryogenesis has been described for Phalaenopsis (Young et al., 2000; Park et al., 2002; Hsu and Chen, 2003). PLBs are also reported to be equivalent to somatic embryos in other plants (Chen and Chang, 2000). In addition, indirect somatic embryogenesis of orchids was achieved through callus induction. A callus with high-regeneration capacity and embryogenic potential for PLB regeneration was achieved using leaf segments (Park et al., 2002), seed-derived protocorms (Lin et al., 2000), and shoot tips (Tokuhara and Mii, 2001). However, genetic variation during regeneration may be based on ploidy levels in individual cells of callus tissues as well as unbalanced growth regulators in the culture medium; thus, somaclonal variation may be a concern when using these explants for PLB regeneration (Martelli et al., 1993).

Growth regulators, particularly auxins, cytokinins, abscisic acid, and ethylene, control in vitro morphogenetic responses in a wide range of plant species (Biondi et al., 1998). Ethylene has both positive and negative effects on callus growth, shoot and root production, and embryogenesis depending on the plant species and physiological state. A high level of endogenous ethylene was detected during callus induction and in developing somatic embryos of Medicago sativa L. (Kępczyńska et al., 2009). The effect of ethylene on in vitro cultures can be examined by adding precursors or inhibitors of ethylene biosynthesis or perception. Addition of the ethylene stimulator methylglyoxal bis (guanylhydrazone) or an ethylene precursor, 1-aminocyclopropanecarboxylic acid (ACC), induced somatic embryogenesis in Medicago truncatula (Mantiri et al., 2008) and Oncidium (Chen and Chang, 2003). However, ACC suppressed somatic embryogenesis in mango nucellar explants (Litz and Yurgalevitch, 1997). 
Early exposure of dark-treated cotyledon explants of Arabidopsis to ethylene stimulated shoot regeneration (Nameth et al., 2013). Sliver nitrate can inhibit ethylene perception and aminoethoxyvinylglycine (AVG) inhibits ethylene biosynthesis. Silver nitrate $\left(\mathrm{AgNO}_{3}\right)$ enhanced somatic embryo formation from a callus in Coffea canephora (Kumar et al., 2007), and AVG stimulated somatic embryogenesis in white spruce (Kong and Yeung, 1994). Silver ions decreased the mean number of embryos/plantlets in a Datura metel anther culture (Babbar and Gupta, 1986) and AVG reduced embryogenesis in a carrot suspension culture (Nissen 1994). Shoot induction in transgenic plants overexpressing the KNAT2 homeodomain protein was enhanced by cytokinin and inhibited by ethylene (Hamant et al., 2002).

1-Aminocyclopropane-carboxylic acid synthetase (ACS) and ACC oxidase (ACO), enzymes responsible for ethylene biosynthesis, have been studied during bud regeneration. Expression of antisense $A C O$ and $A C S$ inhibited ethylene production in transgenic melon and tobacco enhanced shoot regeneration (Ma et al., 2006). However, $A C S$ and $A C O$ expression levels were greater in embryogenic tissue and somatic embryos than in a non-embryogenic callus in $M$. truncatula, and the genes were expressed at an early growth stage as well as throughout the culture period (Mantiri et al., 2008). ACS members showed differential upregulation during the proliferation and maturation of somatic embryos from a callus of Pinus sylvestris (Lu et al., 2011). Timing of chemical treatment was critical for ethylene production and proper application of ethylene inhibitors or precursors at an appropriate physiological stage of barley and M. sativa L. explants affected the regeneration capability (Tyagi and Dahleen, 2011).

Physiological and molecular changes during Phalaenopsis PLB formation and proliferation have not been explored. Therefore, we examined how ethylene affects the formation of secondary PLBs from primary PLBs induced in wounded leaf explants of Phalaenopsis and the activity of regulatory components in ethylene biosynthesis and signal pathways during PLB regeneration.

\section{MATERIAL AND METHODS}

\section{Plant material and preparation of explants}

The flower stalk nodes of Phalaenopsis Tropican Lady were used as explants for in vitro culture to induce shoot formation and were subcultured in the dark for 4 months to obtain etiolated shoots as described in our previous study (Hsu and Chen, 2003). Newly developed young etiolated leaves from shoots were cut into 5 x 10 -mm segments and cultured on modified MS medium, which includes 1/4-strength macro-elements and full-strength micro-elements, glycine, and vitamins of the MS medium (Murashige and Skoog, 1962) supplemented with 0.5 $\mathrm{mg} / \mathrm{L}$ thidiazuron (TDZ), $7 \mathrm{~g} / \mathrm{L}$ agar (Sigma-Aldrich, St. Louis, MO, USA), and $30 \mathrm{~g} / \mathrm{L}$ sucrose (Hsu and Chen, 2003). Explants were incubated in the dark at $25^{\circ} \pm 2^{\circ} \mathrm{C}$. Primary PLBs developed on leaf sections after 4 months were used as explants for PLB proliferation experiments.

\section{Physical wounding, PLB proliferation and plantlet conversion}

Primary PLBs induced from leaf segments were excised and left whole or cut using a surgical blade into intact whole PLBs, bisectioned PLBs, trisectioned PLBs, or longitudinally sectioned PLBs (Figure 1A-H). To determine whether the orientation of the cut explant affects regeneration, the cut surface or the unwounded side was placed in direct contact with the me- 
dium. A total of 8 treatments were used. The induction medium consisted of $3 \mathrm{~g} / \mathrm{L}$ Hyponex fertilizer $\left(7 \mathrm{~N}-6 \mathrm{P}_{2} \mathrm{O}_{5}-19 \mathrm{~K}_{2} \mathrm{O}\right), 1 \mathrm{~g} / \mathrm{L}$ Bacto-tryptone, $50 \mathrm{~g} / \mathrm{L}$ potato homogenate, $50 \mathrm{~g} / \mathrm{L}$ banana homogenate, $30 \mathrm{~g} / \mathrm{L}$ sucrose, $2 \mathrm{~g} / \mathrm{L}$ activated charcoal, and $7.5 \mathrm{~g} / \mathrm{L}$ agar (Sigma-Aldrich). The medium was adjusted to $\mathrm{pH} 5.6$ before autoclaving for $20 \mathrm{~min}$ at $121^{\circ} \mathrm{C}$ and $1.21 \mathrm{~kg} / \mathrm{cm}^{2}$ and $25 \mathrm{~mL}$ was poured on a plastic Petri dish for solidification at ambient temperature. A total of 25 explants were cultured on each Petri dish as a replicate, with 4 replications for each cutting treatment. Cultures were maintained at $25 \pm 2^{\circ} \mathrm{C}$ under a 12 -h photoperiod with $23.2 \mu \mathrm{mol} \mathrm{m}^{-2}$ $\mathrm{s}^{-1}$ supplied by cool-white fluorescent lamps (Philips, TLD36W/54 NS). The regeneration of secondary PLBs was observed once per week for 5 weeks.

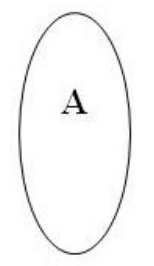

Intact (control)

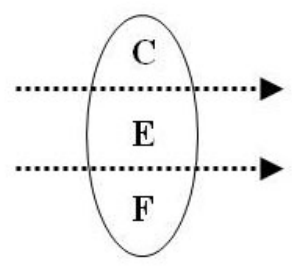

Trisectioned

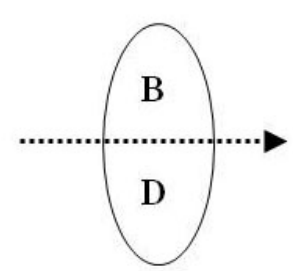

Bisectioned

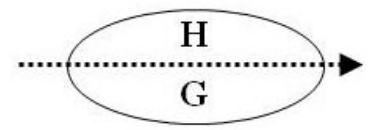

Longitudinal section

Figure 1. Different cutting types of protocorm-like bodies from Phalaenopsis Tropican Lady.

To encourage the conversion of PLBs to plantlets, regenerated secondary PLBs were cultured for 4 months in 500-mL flasks containing regeneration medium of $2 \mathrm{~g} / \mathrm{L}$ Hyponex $\left(7 \mathrm{~N}-6 \mathrm{P}_{2} \mathrm{O}_{5}-19 \mathrm{~K}_{2} \mathrm{O}\right), 1 \mathrm{~g} / \mathrm{LB}$ acto-tryptone, $50 \mathrm{~g} / \mathrm{L}$ potato homogenate, $80 \mathrm{~g} / \mathrm{L}$ banana homogenate, $20 \mathrm{~g} / \mathrm{L}$ sucrose, $2 \mathrm{~g} / \mathrm{L}$ activated charcoal, and $7.5 \mathrm{~g} / \mathrm{L}$ agar. The flasks were plugged with rubber and a hole that had been drilled in the center of the stopper was plugged with cotton. Light and temperature conditions were as previously described. For acclimatization, rooted plantlets were transferred to $6-\mathrm{cm}$ transparent plastic pots containing wet sphagnum moss, maintained at approximately $80 \%$ relative humidity in a greenhouse, and fertilized once biweekly with Peters $20 \mathrm{~N}-20 \mathrm{P}_{2} \mathrm{O}_{5}-20 \mathrm{~K}_{2} \mathrm{O}$ water-soluble fertilizer that had been diluted 2000 -fold.

\section{Effect of ethylene precursors and inhibitors on secondary PLB proliferation}

The basal half of a primary PLB, after removing the bisectioned apical top, was used 
as an explant. $\mathrm{ACC}, \mathrm{AVG}, \mathrm{AgNO}_{3}$, and ethephon at $0,25,50$, and $100 \mu \mathrm{M}$, respectively, were added to the induction medium. All chemicals were dissolved in sterile water, passed through a $0.22-\mu \mathrm{m}$ Nalgene syringe filter, and added to the cooled medium after autoclaving. Ten explants were cultured on each Petri dish as a replicate with 4 replicates for each treatment. Cultures were maintained at $25^{\circ} \mathrm{C}$ with a 12 -h/12-h light/dark photoperiod and light intensity $23.2 \mu \mathrm{mol} \mathrm{m} \mathrm{m}^{-2} \mathrm{~s}^{-1}$ supplied by cool-white fluorescent lamps (Philips, TLD36W/54 NS).

\section{Statistical analysis}

Data were analyzed by analysis of variance and differences were compared by the Duncan multiple range test using SAS v8.02 (SAS Institute, Cary, NC, USA).

\section{Gas chromatography of ethylene levels}

On the basis of preliminary experiments, $100 \mu \mathrm{M}$ ethylene precursors and inhibitors were used because of their effects on ethylene production in proliferating PLBs in culture flasks. For each treatment, 30 explants of the basal half of PLBs were transferred to $125-\mathrm{mL}$ flasks containing $30 \mathrm{~mL}$ regeneration medium as described. The flasks were plugged with a rubber stopper with a hole drilled in the center, which was plugged with cotton, and the flasks were incubated at $25^{\circ} \pm 2{ }^{\circ} \mathrm{C}$ under a 12 -h/12-h light/dark period and light intensity of $23.2 \mu \mathrm{mol} \mathrm{m}^{-2} \mathrm{~s}^{-1}$. Samples of $1 \mathrm{~mL}$ gas were withdrawn from each flask and injected into a gas chromatograph (GC-8000 ${ }^{\mathrm{TOP}}$; CE Instruments, Westhoughton, UK) for ethylene measurement at different times during culture $(0,1,2,3,4$, and 5 weeks). The gas chromatograph was equipped with a flame ionization detector and Supelco column (CARBOXEN-1000, 5FT x $1 / 8 \mathrm{IN}$, Sigma-Aldrich) with nitrogen as the carrier gas at a flow rate of $30 \mathrm{~mL} / \mathrm{min}$. The temperature was set to $160^{\circ} \mathrm{C}$ for the column and $220^{\circ} \mathrm{C}$ for the injector for flame ionization detection $\left(\mathrm{GC}-8000^{\mathrm{TOP}}\right)$. Three replicate samples per treatment were used for ethylene measurement and the experiment was repeated once. Standard ethylene gas adjusted to various concentrations was measured. A calibration curve was constructed to determine ethylene content in gas samples by interpolation.

\section{RNA extraction, reverse transcription (RT)-PCR, and Southern hybridization}

Total RNA was extracted from regenerated PLBs as described previously (Chang et al., 1993), with some modifications. Briefly, PLBs were frozen in liquid nitrogen and homogenized with preheated extraction buffer $(2 \%$ CTAB, $100 \mathrm{mM}$ Tris-HCl, $\mathrm{pH} 8.0,20 \mathrm{mM}$ EDTA, $1.4 \mathrm{M} \mathrm{NaCl}, 2 \%$ polyvinylpyrrolidone, adding $2 \% \beta$-mercaptoethanol before extraction). After an equal volume of chloroform:isoamyl alcohol (49:1) was added, the extract was incubated at $65^{\circ} \mathrm{C}$ for $30 \mathrm{~min}$ and centrifuged at $13,362 \mathrm{~g}$ at $4^{\circ} \mathrm{C}$ for $15 \mathrm{~min}$. RNA was precipitated overnight at $-80^{\circ} \mathrm{C}$ with $0.3 \mathrm{X}$ volumes of $8 \mathrm{M} \mathrm{LiCl}$. RNA was precipitated with $2.5 \mathrm{X}$ volumes of $100 \%$ ethanol at $-80^{\circ} \mathrm{C}$ for $30 \mathrm{~min}$ and then air-dried in ambient temperature. The RNA pellet was resuspended in DEPC-treated sterile water and aliquots were separated on a $1.2 \%$ agarose gel in $0.8 \mathrm{X}$ TE buffer to examine quality.

First-strand cDNA was synthesized from $2 \mu \mathrm{L}$ total RNA by adding cDNA Synthesis Oligo (dT) $)_{12-18}$ Primer $(10 \mu \mathrm{M}$; Invitrogen, Carlsbad, CA, USA) and dNTP mix $(10 \mu \mathrm{M})$ and reverse transcribed using the SuperScript First-Strand Synthesis System (Invitrogen). 
Gene-specific primers were designed based on highly conserved regions for each gene and used for PCR amplification of the following specific DNA fragments: PhACS2 (AF004663 and AF007213), PhACS3 (AF007214), PhACO (AF004662), constitutive triple response 2 (PhCTR2; LOPX03N-45-2; Chen et al., 2005), ethylene receptor (PhETR; AF055894, AF276235, and AY746972), ethylene response sensor (PhERS; AJ563284 and AF113541), ethylene-insensitive 3 (PhEIN3; AJ316086); PATC149849 (PhGTP) and PhACTIN (Table S1). The PCR conditions included 28 cycles of $95,50-52$, and $72^{\circ} \mathrm{C}$, all for $30 \mathrm{~s}$, in a thermocycler (GeneAmp PCR System 2720; Applied Biosystems, Foster City, CA, USA). PCR products were separated on a $1.2 \%$ agarose gel.

To better determine the transcript level of some weakly expressed genes, we used Southern hybridization of PCR-amplified products with gene-specific probes. The amplified DNA in gel was soaked in $0.4 \mathrm{~N} \mathrm{NaOH}$ for $30 \mathrm{~min}$ and then transferred to GeneScreen Plus membrane (Perkin Elmer, Waltham, MA, USA). Membranes were washed, cross-linked with UV light, and air-dried. Each membrane was pre-hybridized at $55^{\circ} \mathrm{C}$ for $1 \mathrm{~h}$ in a solution containing $5 \mathrm{X}$ SSC, $0.1 \%$ blocking reagent, $0.1 \% N$-lauroylsarcosine, and $0.02 \%$ SDS and allowed to hybridize with specific probes for $8-16 \mathrm{~h}$ at $55^{\circ} \mathrm{C}$. After hybridization, membranes were washed once in $2 \mathrm{X} \mathrm{SSC}, 0.1 \% \mathrm{SDS}$ at room temperature for $10 \mathrm{~min}$ and twice in $0.5 \mathrm{X} \mathrm{SSC}, 0.1 \% \mathrm{SDS}$ at $65^{\circ} \mathrm{C}$ for $15 \mathrm{~min}$. The membranes were subjected to a chemiluminescent reaction with colorsubstrate (NTB/BCIP stock solution, $100 \mathrm{mM}$ Tris-HCl, $100 \mathrm{mM} \mathrm{NaCl}, 50 \mathrm{mM} \mathrm{MgCl}$, $\mathrm{pH} 9.5$ ) using the DIG DNA Labeling and Detection Kit (Roche, Mannheim, Germany).

\section{RESULTS}

\section{Physical wounding stimulated secondary PLB proliferation}

Primary PLBs were cut in different directions, plated with induction medium and incubated under light. Uncut, intact PLBs produced only minimal secondary PLBs, with a mean of 5.6 PLBs per explant (Table 1 and Figure 2A, A1), and no PLB formation was observed from the apical area of sectioned explants that typically develops into single plantlets with leaves and roots after 5 weeks (Figure 2B, C). In the first week, the apical meristem evolved at the tip soon after cutting a PLB and leaves, followed by roots, emerged after 5 weeks (Figure 2B1, C1). However, basal parts of sectioned explants produced more secondary PLBs (Figure 2D, E, F). Significantly, during first subculture, 21-22 PLBs were produced from bisected (96\%) and trisected (88\%) explants. Because the basal part of a PLB lacks an apical meristem, granulelike structures consisting of cell clumps from wounded PLBs protruded by 2 weeks, and many secondary PLBs developed from epidermal layers proximal to the wound site (Figure 2D1, E1, F1). For longitudinally sectioned explants (Figure 2G, H), 83-91\% responded and produced 1931 secondary PLBs per explant. To examine whether secondary PLB proliferation was reproducible, PLBs were recut after full development at 5 weeks and subcultured at 5-week intervals, 4 times (Table 1). For each subculture, sectioned PLBs could regenerate more secondary PLBs, and the multiplication rate during the 4 subcultures was consistent at 15-19 PLBs (Table 1). The cytoplasm-rich epidermal cells of PLB explants began to divide at 2 weeks after beginning culture (Figure 3A). Many dividing cells formed small growth centers protruding above the surface of epidermal cell layers, with continual division within these protuberances into PLBs after 4 weeks (Figure 3B). Upon transfer of fully developed secondary PLBs to regeneration medium, they developed into plantlets by 4 to 6 weeks without extra growth regulators, and 
after 10 more weeks, were ready for transplanting to 6 -cm pots containing sphagnum moss and grown in a greenhouse (Figure 4A-D). After one more transplanting into 9-cm pots and wrapping with more sphagnum moss and growth for 8 months, these clonal plants were successfully induced to spike in a cool room of day/night temperature $26^{\circ} / 20^{\circ} \mathrm{C}$ in approximately 4 weeks, and the first flower opened about 4 months later. The flowers and inflorescence all appeared normal, suggesting that the micropropagation procedure could be used for routine clonal propagule production. To simplify the physical wounding and culture operation, we used the basal parts from bisectioned PLBs for subsequent ethylene and inhibitor treatments.

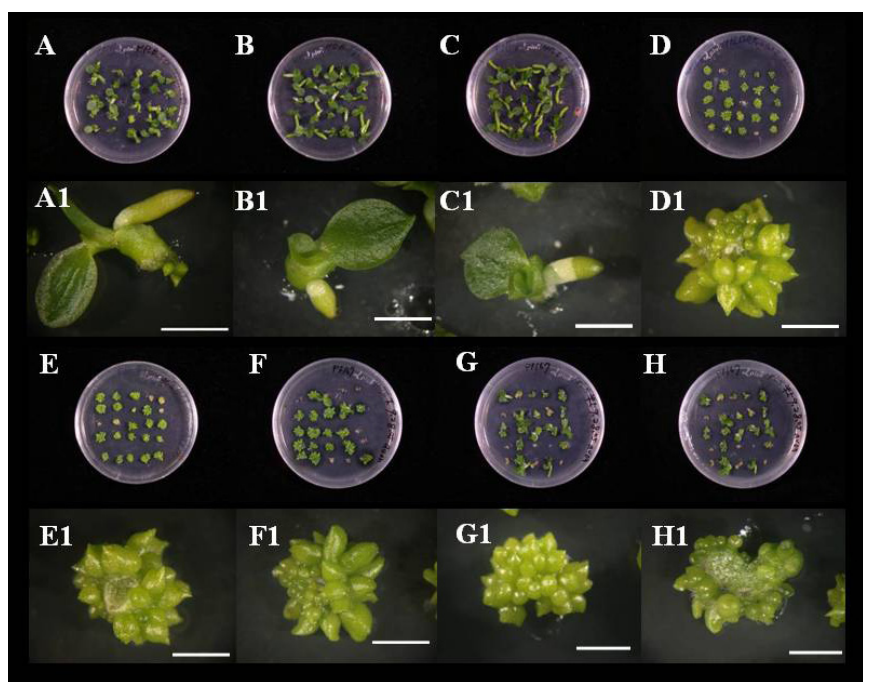

Figure 2. Development of secondary protocorm-like bodies (PLBs) and proliferation from primary PLB explants of Phalaenopsis Tropican Lady after culture for 5 weeks. Bars $=5 \mathrm{~mm}$. A. Excised whole intact PLBs; B. apical part of bisectioned PLBs; C. apical part of trisectioned PLBs; D. basal part of bisectioned PLBs; E. middle part of trisectioned PLBs; F. basal part of trisectioned PLBs; G. cut edge of longitudinally sectioned PLBs facing down on the medium; H. cut edge of longitudinally sectioned PLBs facing up on the medium.
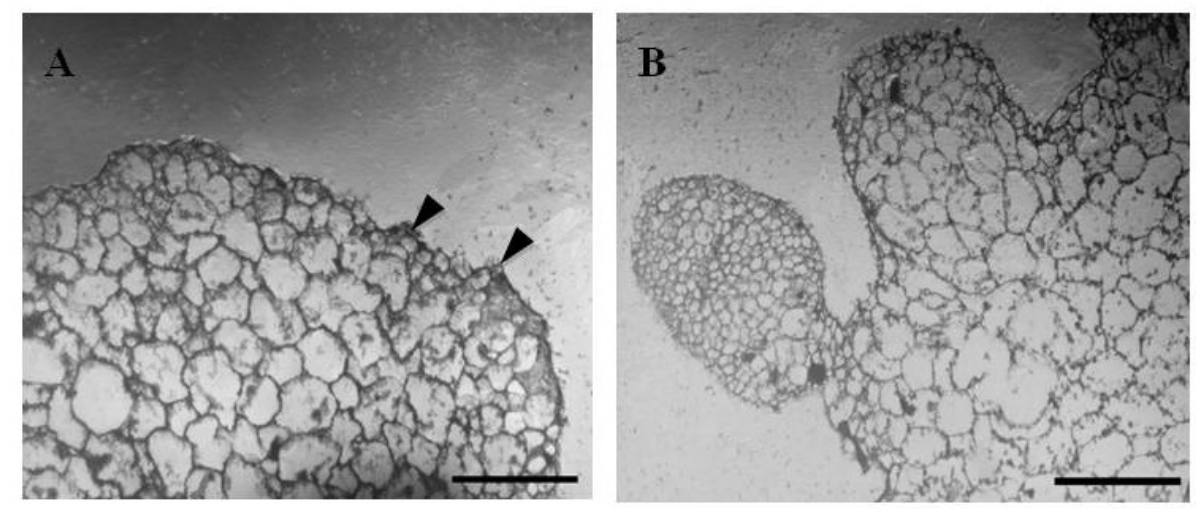

Figure 3. Histology of cross-sectioned protocorm-like bodies (PLBs) explants of Phalaenopsis Tropican Lady showing PLB formation. A. Initial cellular protuberance (arrows heads) from epidermal layers after culture for 2 weeks. Bars = $1 \mathrm{~mm}$; B. expansion and fully developed PLB from epidermal layer after culture for 4 weeks (bar $=1 \mathrm{~mm}$ ). 


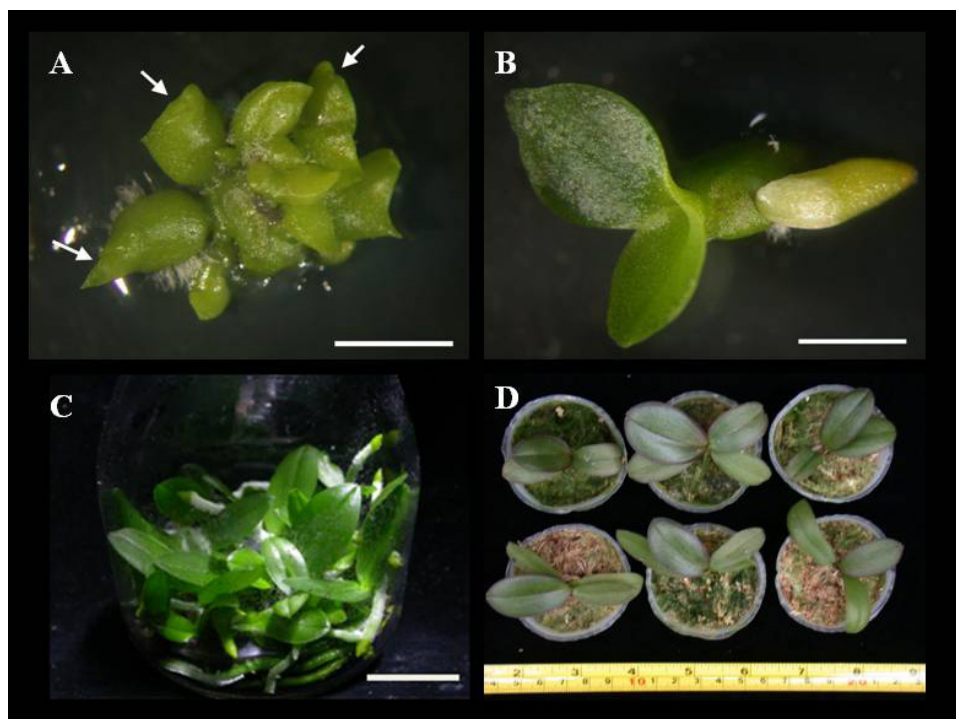

Figure 4. Regenerated protocorm-like bodies (PLBs) and converted plantlets of Phalaenopsis Tropican Lady. A. Regenerated PLBs and their apexes (arrows) from a primary PLB after culture for 6 weeks $(b a r=3 \mathrm{~mm})$; $\mathbf{B}$. regenerated plantlet from a PLB after culture for 6 weeks (bar $=3 \mathrm{~mm}$ ); C. regenerated plantlets subcultured in flasks for 4 months ready for transplanting ( $\mathrm{bar}=20 \mathrm{~mm}$ ); D. regenerated plants cultured on sphagnum moss in 6-cm plastic pots.

Table 1. Effect of cutting type during 4 subcultures at 5-week intervals on proliferation of protocorm-like bodies (PLBs) of Phalaenopsis Tropican Lady.

\begin{tabular}{|c|c|c|c|c|c|c|c|c|}
\hline & \multicolumn{2}{|c|}{ First subculture } & \multicolumn{2}{|c|}{ Second subculture } & \multicolumn{2}{|c|}{ Third subculture } & \multicolumn{2}{|c|}{ Fourth subculture } \\
\hline & $\begin{array}{l}\text { PLB formation } \\
(\%)\end{array}$ & $\begin{array}{c}\text { Mean No. of } \\
\text { PLBs per explant }\end{array}$ & $\begin{array}{l}\text { PLB formation } \\
(\%)\end{array}$ & $\begin{array}{c}\text { Mean No. of } \\
\text { PLBs per explant }\end{array}$ & $\begin{array}{l}\text { PLB formation } \\
(\%)\end{array}$ & $\begin{array}{c}\text { Mean No. of } \\
\text { PLBs per explant }\end{array}$ & $\begin{array}{l}\text { PLB formation } \\
(\%)\end{array}$ & $\begin{array}{c}\text { Mean No. of } \\
\text { PLBs per explant }\end{array}$ \\
\hline A & 26.3 & $5.6^{\mathrm{d}}$ & 0 & $0^{\mathrm{d}}$ & 0 & $0^{\mathrm{e}}$ & 0 & $0^{\mathrm{e}}$ \\
\hline B & 0 & $0^{\mathrm{e}}$ & 0 & $0^{\mathrm{d}}$ & 0 & $0^{\mathrm{e}}$ & 0 & $0^{\mathrm{e}}$ \\
\hline $\mathrm{C}$ & 0 & $0^{\mathrm{e}}$ & 0 & $0^{\mathrm{d}}$ & 0 & $0^{\mathrm{e}}$ & 0 & $0^{\mathrm{e}}$ \\
\hline D & 96.3 & $21.1^{\mathrm{b}}$ & 73.1 & $15.9^{\mathrm{b}}$ & 68.4 & $17.2^{\mathrm{b}}$ & 68.4 & $15.4^{\mathrm{c}}$ \\
\hline $\mathrm{E}$ & 75 & $22.7^{\mathrm{b}}$ & 75.6 & $15.1^{\mathrm{b}}$ & 56.3 & $19^{\mathrm{ab}}$ & 50 & $19.9^{\mathrm{a}}$ \\
\hline $\mathrm{F}$ & 88.6 & $22.85^{\mathrm{b}}$ & 61.3 & $21.9^{\mathrm{a}}$ & 46.8 & $19.5^{\mathrm{a}}$ & 62.5 & $15.9^{\mathrm{c}}$ \\
\hline G & 83 & $19.1^{\mathrm{c}}$ & 50.0 & $9.6^{\mathrm{c}}$ & 38.8 & $11.5^{\mathrm{d}}$ & 41.3 & $12^{\mathrm{c}}$ \\
\hline $\mathrm{H}$ & 91 & $31.7^{\mathrm{a}}$ & 43.8 & $14.4^{\mathrm{b}}$ & 28.8 & $14.7^{\mathrm{c}}$ & 47.5 & $17.3^{\mathrm{b}}$ \\
\hline
\end{tabular}

Data represent the mean of 4 replications. Means followed by the same letter in each column are not significantly different by the Duncan multiple range test $(\mathrm{P}<0.001) \mathrm{A}=$ excised whole intact $\mathrm{PLBs} ; \mathrm{B}=$ apical part of bisectioned PLBs; $\mathrm{C}=$ apical part of trisectioned PLBs; $\mathrm{D}=$ basal part of bisectioned PLBs; $\mathrm{E}=$ middle part of trisectioned PLBs; $F$ = basal part of trisectioned PLBs; $G$ = cut edge of longitudinally sectioned PLBs facing down on the medium; $\mathrm{H}=$ cut edge of longitudinally sectioned PLBs facing up on the medium.

\section{Effect of ethylene precursors and inhibitors on proliferation of PLBs}

The regeneration efficiency of secondary PLBs from sectioned primary PLBs depended on the type and concentration of ethylene precursors or inhibitors in the medium. Approximately $64 \%$ of explants produced secondary PLBs in control medium without ethylene precursors or inhibitors. Ethylene precursors ACC and ethephon increased the regeneration 
percentage, and the regeneration was slightly lower with AVG at high concentrations (50-100 $\mu \mathrm{M})$ than with $\mathrm{ACC}$ and ethephon; $\mathrm{AgNO}_{3}$ showed a variable effect but in general higher effect than control treatment (Table 2). Ethephon at $100 \mu \mathrm{M}$ increased secondary PLB formation. Thus, ethylene promoted PLB regeneration.

\begin{tabular}{|c|c|c|c|c|}
\hline Ethylene precursors/inhibitors & Concentration $(\mu \mathrm{M})$ & PLB formation (\%) & Mean No. of PLBs per explant & Explant death (\%) \\
\hline Control & 0 & $64.1^{\mathrm{bc}}$ & $14.2^{\text {ef }}$ & $30.8^{\text {abc }}$ \\
\hline \multirow[t]{3}{*}{$\mathrm{ACC}$} & 25 & $76.5^{\mathrm{ab}}$ & $14.9^{\text {def }}$ & $20.6^{\mathrm{bc}}$ \\
\hline & 50 & $91.4^{\mathrm{a}}$ & $13.8^{\mathrm{f}}$ & $8.6^{\mathrm{c}}$ \\
\hline & 100 & $78.9^{\mathrm{ab}}$ & $16.0^{\text {cdef }}$ & $18.4^{\mathrm{bc}}$ \\
\hline \multirow[t]{3}{*}{ AVG } & 25 & $82.5^{\mathrm{ab}}$ & $18.6^{\mathrm{ab}}$ & $15.0^{\mathrm{bc}}$ \\
\hline & 50 & $75.0^{\mathrm{abc}}$ & $16.6^{\text {bcd }}$ & $25.0^{\mathrm{bc}}$ \\
\hline & 100 & $70.0^{\mathrm{abc}}$ & $19.1^{\mathrm{a}}$ & $30.0^{\text {abc }}$ \\
\hline \multirow{3}{*}{$\mathrm{AgNO}_{3}$} & 25 & $82.1^{\mathrm{ab}}$ & $20.2^{\mathrm{a}}$ & $17.9^{\mathrm{bc}}$ \\
\hline & 50 & $52.5^{\mathrm{c}}$ & $18.4^{\text {abc }}$ & $47.5^{\mathrm{a}}$ \\
\hline & 100 & $82.5^{\mathrm{ab}}$ & $19.6^{\mathrm{a}}$ & $17.5^{\mathrm{bc}}$ \\
\hline \multirow{3}{*}{ Ethephon } & 25 & $70.0^{\mathrm{abc}}$ & $19.6^{\mathrm{a}}$ & $30.0^{\text {abc }}$ \\
\hline & 50 & $69.2^{\text {abc }}$ & $19.1^{\mathrm{a}}$ & $30.8^{8 \mathrm{abc}}$ \\
\hline & 100 & $87.5^{\mathrm{ab}}$ & $19.1^{\mathrm{a}}$ & $12.5^{\mathrm{bc}}$ \\
\hline \multicolumn{5}{|l|}{ Significance } \\
\hline Treatment & & ns & $* * *$ & ns \\
\hline Concentration & & ns & $* *$ & ns \\
\hline Treatment $\mathrm{x}$ Concentration & & $*$ & ns & $*$ \\
\hline
\end{tabular}

Data represent the mean of 4 replications, and means followed by the same letter in each column are not significantly different by the Duncan multiple range test. ${ }^{\mathrm{ns}}$, $* * * * * *$ Non-significant, $\mathrm{P}<0.05, \mathrm{P}<0.01$, and $\mathrm{P}<0.001$, respectively (factorial experiment in complete randomized design arrangement). ACC $=1$-aminocyclopropanecarboxylic acid; $\mathrm{AVG}=$ aminoethoxyvinylglycine; $\mathrm{AgNO}_{3}=$ sliver nitrate; ethephon = 2-chloroethylphosphonic acid.

\section{Effect of ethylene precursors and inhibitors on ethylene production}

In a preliminary experiment, $100 \mu \mathrm{M} \mathrm{ACC}, \mathrm{AVG}, \mathrm{AgNO}_{3}$, and ethylene were tested for their effect on endogenous ethylene production. Ethylene was produced at the basal level in control explants grown on hormone-free media. $\mathrm{AVG}, \mathrm{ACC}$, and $\mathrm{AgNO}_{3}$ initially slightly increased ethylene level at week 1 , which decreased to the basal level and slightly peaked at 4 weeks (Figure 5). Ethephon induced higher ethylene production, which peaked at weeks 1 and 4. The increased ethylene production in PLB explants appeared to be associated with the formation of secondary PLBs at week 4 (Figure 5 and Table 2).

\section{Effect of ethylene on gene expression}

To investigate the effect of wounding on the expression of ethylene biosynthetic and signaling genes, PLBs were bisected and, with uncut intact PLBs as a control, were cultured for $6,12,24,48$, and $72 \mathrm{~h}$ in induction medium. The mRNA levels of PhACS2 and PhACS3 were increased after wounding, and the level of $P h A C O$ was increased and maintained for a longer period of time than with the control treatment (Figure 6A, B). A similar pattern was observed for genes related to signal transduction, including receptors (PhETR, PhERS, and PhCTR2), a positive regulator (PhEIN3), and a transient upregulator (PhGTP). The levels of PhETR, PhERS, PhCTR2, and PhEIN3 were higher in wounded than non-wounded PLBs. 


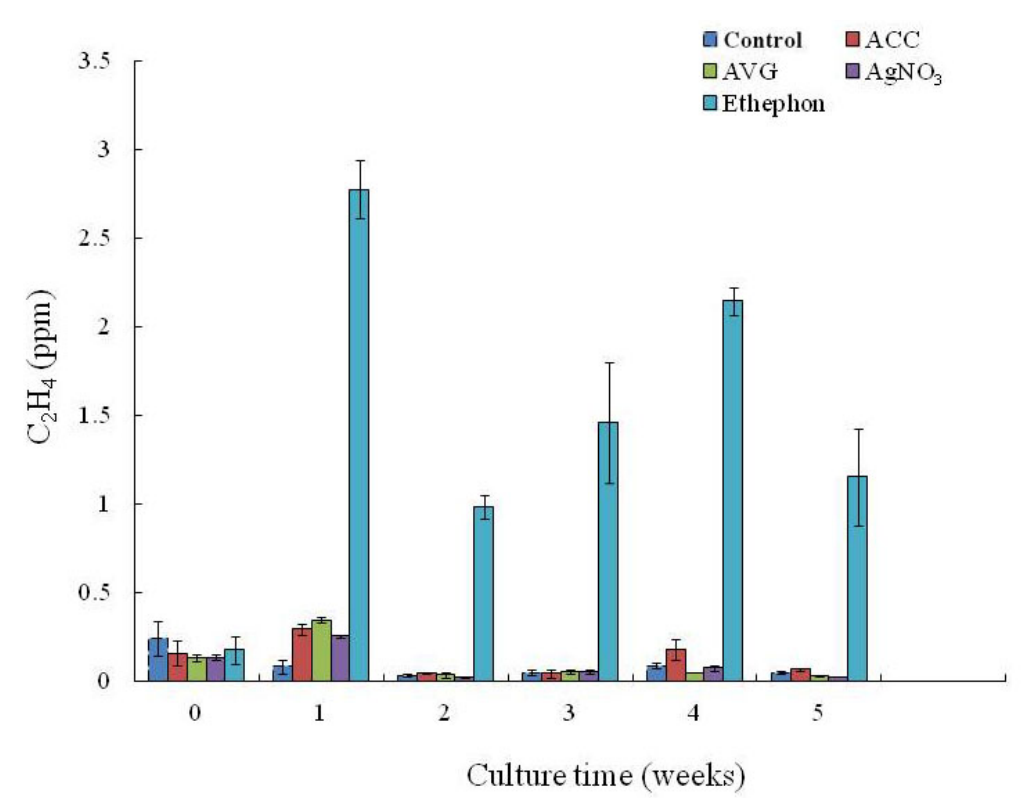

Figure 5. Effect of ethylene precursors and inhibitors on ethylene production in wounded protocorm-like bodies of Phalaenopsis Tropican Lady during a 5-week culture. Data are reported as means \pm SD. For abbreviations, see Table 2.

$$
\text { A }
$$

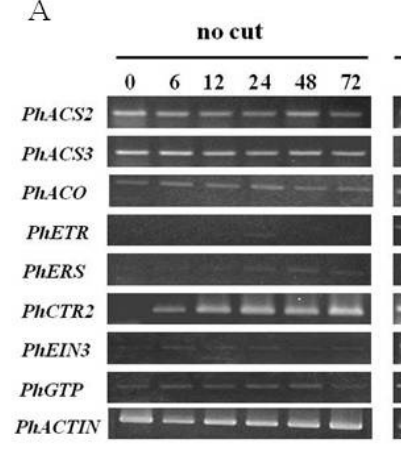

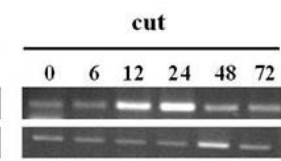
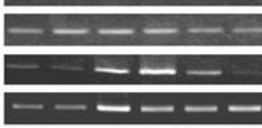

- - - - - -
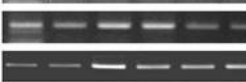

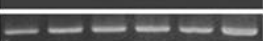

B

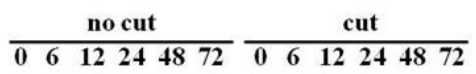

PhACS2

PhACS3

PhACO

PIETR

PILERS

PICTR2

PhEIN3

PhGTP

PhACTIN

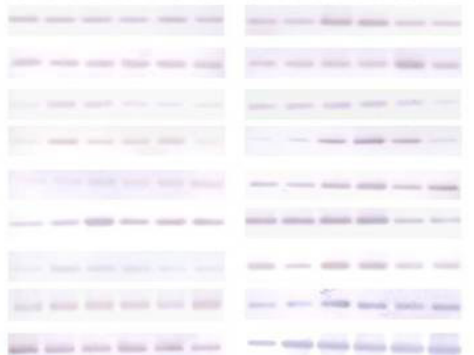

Figure 6. Expression of ethylene biosynthesis and signaling genes in wounded (bisected) protocorm-like bodies of Phalaenopsis Tropican Lady. ACTIN was used as a housekeeping control. A. RT-PCR analysis of mRNA levels. B. Southern blot of RT-PCR products.

To examine whether genes in the ethylene pathway are affected in wounded and developing PLBs treated with ethylene precursors and inhibitors, we examined the expression of ethylene biosynthesis and signaling genes. PhACO level was increased in wounded PLBs with both ACC and ethephon at $6 \mathrm{~h}$ (Figure 7A, B). AVG and $\mathrm{AgNO}_{3}$ inhibited the mRNA level of $P h A C S 3$ compared with control treatment after $6 \mathrm{~h}$, while the level of $P h A C O$ was decreased only at $6 \mathrm{~h}$ and subsequently regained the control expression. ACC treatment was more effective than ethephon at stimulating the mRNA accumulation of PhASC2, PhASC3, and PhACO. 

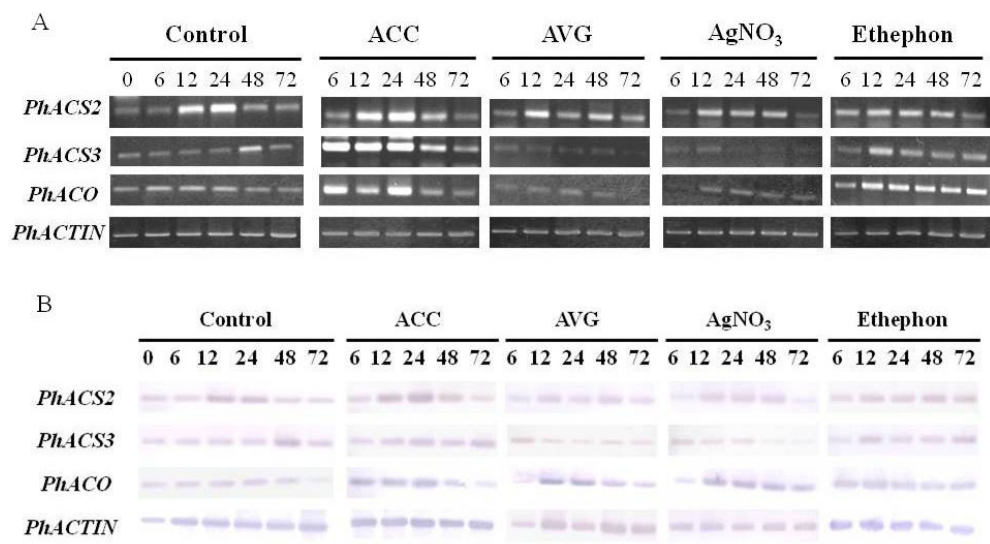

Figure 7. Effect of ethylene precursors and inhibitors on the expression of ethylene biosynthetic genes in wounded (bisected) protocorm-like bodies of Phalaenopsis. ACTIN was used as a loading control. A. RT-PCR analysis of mRNA levels. B. Southern blot of RT-PCR products. For abbreviations, see Table 2.

The expression of PhETR and PhERS was increased following ethylene treatment and decreased with ethylene inhibition (Figure 8A, B). The mRNA level of PhETR was increased following treatment with $\mathrm{ACC}$ and ethephon at $6 \mathrm{~h}$, but inhibited with $\mathrm{AVG}$ and $\mathrm{AgNO}_{3}$ at $48 \mathrm{~h}$. Expression of PhERS was higher with ethylene than with the control treatment. AVG and $\mathrm{AgNO}_{3}$ mitigated the accumulation of $P h E R S$, which was significantly decreased with AVG beginning at $6 \mathrm{~h}$. The expression pattern of PhCTR2 was similar to that of the ethylene receptors (PhETR and PhERS) with ethylene and inhibitor treatments between 12 and $48 \mathrm{~h}$. The expression pattern of PhEIN3 was similar to that of ethylene receptors, with ethephon more effectively enhancing the transcription than ACC. In addition, AVG decreased the level of PhEIN3 at $48 \mathrm{~h}$ and $\mathrm{AgNO}_{3}$ reduced the level at $72 \mathrm{~h}$. A similar pattern was observed for $P h G T P$ with the ethylene precursor and inhibition.
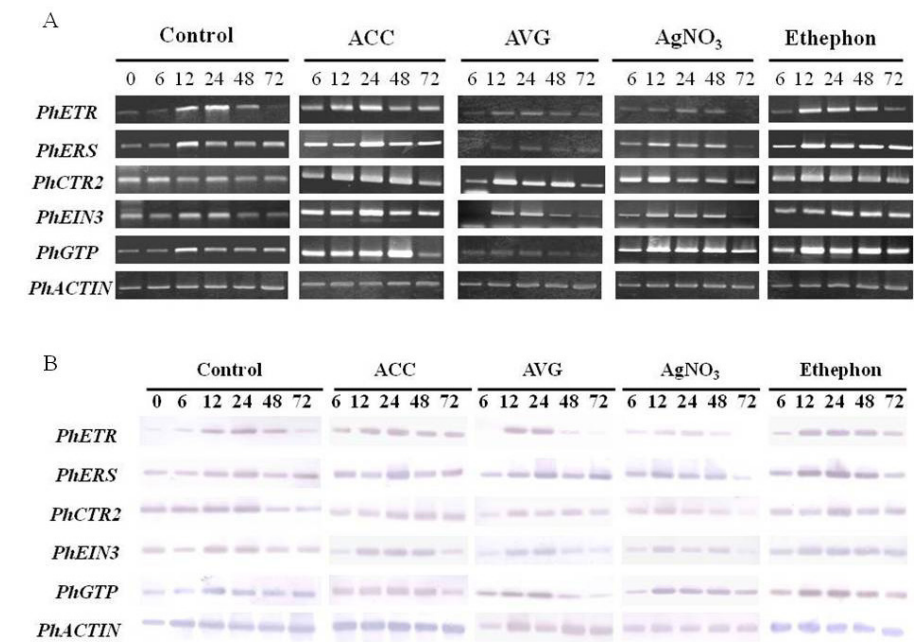

Figure 8. Effect of ethylene precursors and inhibitors on the expression of ethylene perception and signaling genes in wounded protocorm-like bodies of Phalaenopsis. ACTIN was a loading control. A. RT-PCR analysis of mRNA levels. B. Southern blot of RT-PCR product. For abbreviations, see Table 2. 


\section{DISCUSSION}

In this study, we developed a Phalaenopsis orchid model that was used to investigate the effect of physical wounding on the induction of embryonic stem cells in primary PLBs, which subsequently developed into PLBs. Few secondary PLBs were produced on whole PLB explants with only limited wounding. The capacity of PLB explants to induce more secondary PLBs appeared to depend on physically cutting and removing the apical area, which developed later into only one plantlet. PLB segments from the basal area formed a similar number of secondary PLBs with bisecting or trisecting tissue, although trisecting generally produced fewer PLBs than did bisecting (Table 1). The slightly lower formation with trisectioned PLBs was probably due to smaller explant size and the susceptibility to browning and reduced survival in culture medium, perhaps because of the wounding response and ethylene level. The multiplication rate of 15-19 PLBs per explant could be maintained for at least 4 subcultures. Therefore, a large number of PLBs could be obtained within a short time (5 weeks) after subculture and by repeating the wounding and plating process.

PLBs induced from leaf segments have been described for micropropagation of many orchids. Amaki and Higuchi (1989) reported that segments from the basal parts of PLBs can produce PLBs in Doritaenopsis in one long-term culture. Other reports revealed that PLB explants are useful for inducing callus and subsequent regeneration of PLBs in Phalaenopsis (Young et al., 2000), Dendrobium (Nayak et al., 2002), and Cymbidium (Nayak et al., 2002). These studies typically used a higher concentration of growth regulators, auxin, and cytokinin, than was used in our study, which may produce somaclonal variation. Our study used low cytokinin levels for the initial induction of PLBs from etiolated leaf segments. Subsequent PLB proliferation in hormone-free medium resulted in normal morphologic features at flowering. This wound-and-culture procedure may be an effective commercial technology for micropropagation of Phalaenopsis orchids.

Ethylene is involved in somatic embryogenesis of many plants. Chen and Chang (2003) reported the promotion of an embryogenic response in leaf tips and adaxial sides of Oncidium cultured on medium supplemented with a high concentration of ACC (50 mM). Otherwise, ethylene has an inhibitory effect; addition of ACC to medium reduced numbers of somatic embryos in safflower (Mandal et al., 2001) and mango (Litz and Yurgalevitch, 1997). Using transgenic $M$. truncatula, Mantiri et al. (2008) found the early induction of expression of ethylene biosynthesis genes $A C S$ and $A C O$, which continued throughout the culture period in embryogenic callus. However, leaf and cotyledon explants of Cucumis melo from transgenic plants carrying anti-sense $A C O$ and exhibiting low ACC oxidase activity and low ethylene production showed greatly enhanced shoot regeneration capacity; inhibition of ethylene production allowed for shoot regeneration (Amor et al., 1998).

Our study of ethephon, as well as of ACC, revealed an association between enhanced formation and multiplication of PLBs as compared with hormone-free treatment. A high level of AVG suppressed ethylene biosynthesis, and thus PLB formation (Table 2 and Figures 5 and 7), indicating a role of ethylene in PLB formation of Phalaenopsis. Auxin has long been thought to play a crucial role in inducing somatic embryogenesis (Duditis et al., 1991). Extensive cross-talk exists between ethylene and auxin during synthesis and signaling. Auxin induces ethylene biosynthesis by upregulating ACC synthase (Sakai and Imaseki, 1971), and ethylene stimulates auxin biosynthesis (Ivanchenko et al., 2008). Strader et al. (2009) indicated that $\mathrm{Ag}^{+}$-enhanced indole acetic acid efflux is independent of its effect on ethylene per- 
ception and that caution is warranted when interpreting studies that used $\mathrm{AgNO}_{3}$ to dissect the extensive interactions between ethylene and auxin pathways. Although ethylene action was thought to be inhibited by $\mathrm{AgNO}_{3}$, this compound may disturb the cuticle layer, and thus enhance cell proliferation. Therefore, the percentage of embryogenic explants increased significantly with $\mathrm{AgNO}_{3}$, to increase the number of PLBs. In our study, the apical (dorsal) area of PLBs generally regenerated into a plantlet, and the basal parts formed more secondary PLBs, thus endogenous auxin redistribution after wounding may play a role in establishing new growth centers of PLBs.

Ethylene may be essential for PLB formation and its effects on secondary PLB formation at low concentration. In our study, ethylene level in PLBs was significantly greater with wounding, with maximal ethylene biosynthesis and PLB maturation at 4 weeks of culture. The ethylene biosynthetic genes $A C S$ and $A C O$ are both induced by wounding (Barry et al., 1996). We showed increased PhACS and PhACO levels in PLB explants that were cut and cultured on hormone-free medium (Figure 6). The above argument is supported by ethylene affecting PLB proliferation and having a positive impact on the promotion of PLB formation.

Although ethylene-regulated somatic embryogenesis has been demonstrated in many plants such as Coffea canephora (Kumar et al., 2007), Oncidium (Chen and Chang, 2003), M. truncatula (Mantiri et al., 2008), and safflower (Mandal et al., 2001), little is known regarding ethylene-related gene regulation during PLB formation of Phalaenopsis. Our study revealed upregulated transcription of ethylene biosynthesis and response genes (Figures 6 and 7), which agrees with PLB induction by ethylene precursors, ACC and ethephon (Table 2). Expression of ACC synthesis genes, PhACS2 and PhACS3, was stimulated by ethylene and continued to accumulate after $12 \mathrm{~h}$. ACS activity is inhibited by AVG (Baker et al., 1977). After exposing wounded PLBs to AVG for $24 \mathrm{~h}$, the expression of ethylene biosynthesis genes decreased (Figure 7) and AVG showed decreased PLB induction (Table 2). Silver ions, which are known to be an effective inhibitor of ethylene responses, act at the receptor level. $\mathrm{Ag}^{+}$bound to the ethylene receptor affected downstream gene expression (PhCTR2 and PhEIN3) (Figure 8). GTP is a specific gene responding to wounding in Arabidopsis (Cheong et al., 2002). In our wounded Phalaenopsis PLB explants, PhGTP expression was increased at $12 \mathrm{~h}$ with $\mathrm{AgNO}_{3}$ (Figure 8).

Ethylene perception is required by the membrane-associated receptor gene family (ETR and ERS), which was further enhanced by ethylene in Arabidopsis (Hua and Meyerowitz, 1998) and rose (Ma et al., 2006). In our study, PhETR and PhERS levels were increased following ethylene treatment (ACC and ethephon) and lowered following $\mathrm{AgNO}_{3}$ treatment. The expression of CTR1, an ethylene receptor-signaling complex with ethylene receptor ETR1, and AtCTR1 was not affected by ethylene in Arabidopsis (Gao et al., 2003). However, $C T R 1$ was previously found to be regulated by ethylene and its level increased during flower opening and fruit ripening in rose (RhCTRI and RhCTR2) and tomato (LeCTR1) (Leclercq et al., 2002). Therefore, expression of PhCTR2 may be induced by ethylene (Figure 8). EIN3 acts downstream of the histidine kinase ethylene receptor, ETR1, and the Raf-like kinase, CTR1, and is a positive regulator in the ethylene signaling pathway (Kendrick and Chang, 2008). The Arabidopsis ein 3 mutant shows a loss of ethylene-mediated effects, including gene expression, the triple response, cell growth inhibition, and accelerated senescence (Chao et al., 1997). LeEILs (EIN3-like) are functionally redundant and positive regulators of multiple ethylene responses that are present throughout plant development (Tieman et al., 2001). In this study, PhEIN3 expression was upregulated with ethylene treatment and decreased with ethylene 
inhibitors (Figure 8), so EIN3 plays an important role in the ethylene response. Expression patterns of these genes provide new information regarding the interactions between ethylene and other signals and may indicate that feedback regulation occurs for the ethylene signaling pathway in PLB formation.

Our study demonstrated that wounded PLBs stimulate ethylene biosynthesis and corresponding gene expression, for stimulation of cell division in epidermal layers and formation of secondary PLBs. Phalaenopsis PLB tissues may be a source of embryogenic stem cells after physical wounding for forming PLBs with culture in the regeneration medium used.

\section{ACKNOWLEDGMENTS}

Research supported by grants from the Agriculture and Food Agency, Council of Agriculture, Taiwan [grant \#101AS-9.1.1-FD-Z2(1) and \#102AS-9.1.1-FD-Z2(1)]. We are grateful to Yi-Jung Tsai and Jian-Zhi Huang for technical assistance.

\section{Supplementary material}

\section{REFERENCES}

Amaki W and Higuchi H (1989). Effects of dividing on the growth and organogenesis of protocorm-like bodies in Doritaenopsis. Sci. Hortic. 39: 63-72.

Amor MB, Guis M, Latché A, Bouzayen M, et al. (1998). Expression of an antisense 1-aminocyclopropane-1-carboxylate oxidase gene stimulates shoot regeneration in Cucumis melo. Plant Cell Rep. 17: 586-589.

Babbar SB and Gupta SC (1986). Putative role of ethylene in Datura metel microspore embryogenesis. Physiol. Plant 68: 141-144.

Baker JE, Wang CY, Lieberman M and Hardenburg R (1977). Delay of senescence in carnations by rhizobitoxine analogue and sodium benzoate. HortScience 12: 38-39.

Barry CS, Blume B, Bouzayen M, Cooper W, et al. (1996). Differential expression of the 1-aminocyclopropane-1carboxylate oxidase gene family of tomato. Plant J. 9: 525-535.

Biondi S, Scaramagli S, Capitani F, Marino G, et al. (1998). Ethylene involvement in vegetative bud formation in tobacco thin layers. Protoplasma 202: 134-144.

Chang S, Puryear J and Cairney J (1993). A simple and efficient method for isolating RNA from pine trees. Plant Mol. Biol. Rep. 11: 113-116.

Chao Q, Rothenberg M, Solano R, Roman G, et al. (1997). Activation of the ethylene gas response pathway in Arabidopsis by the nuclear protein ETHYLENE-INSENSITIVE3 and related proteins. Cell 89: 1133-1144.

Chen JT and Chang WC (2000). Plant regeneration via embryo and shoot bud formation from flower-stalk explants of Oncidium sweet sugar. Plant Cell Tissue Organ Cult. 62: 95-100.

Chen JT and Chang WC (2003). 1-Aminocyclopropane-1-carboxylic acid enhanced direct somatic embryogenesis from Oncidium leaf cultures. Biol. Plant 46: 455-458.

Chen YH, Tsai YJ, Huang JZ and Chen FC (2005). Transcription analysis of peloric mutants of Phalaenopsis orchids derived from tissue culture. Cell Res. 15: 639-657.

Cheong YH, Chang HS, Gupta R, Wang X, et al. (2002). Transcriptional profiling reveals novel interactions between wounding, pathogen, abiotic stress, and hormonal responses in Arabidopsis. Plant Physiol. 129: 661-677.

Duditis D, Bogre L and Gyorgyey J (1991). Molecular and cellular approaches to the analysis of plant embryo development from somatic cells in vitro. J. Cell Sci. 99: 475-484.

Gao Z, Chen YF, Randlett MD, Zhao XC, et al. (2003). Localization of the Raf-like kinase CTR1 to the endoplasmic reticulum of Arabidopsis through participation in ethylene receptor signaling complexes. J. Biol. Chem. 278: 34725-34732.

Hamant O, Nogue F, Belles-Boix E, Jublot D, et al. (2002). The KNAT2 homeodomain protein interacts with ethylene and cytokinin signaling. Plant Physiol. 130: 657-665.

Hsu CC and Chen FC (2003). Plant regeneration from protocorm-like-bodies induced in etiolated leaves of Phalaenopsis aphrodite Rchb. f. J. Chin. Soc. Hort. Sci. 49: 335-342. 
Hua J and Meyerowitz EM (1998). Ethylene responses are negatively regulated by a receptor gene family in Arabidopsis thaliana. Cell 94: 261-271.

Ivanchenko MG, Muday GK and Dubrovsky JG (2008). Ethylene-auxin interactions regulate lateral root initiation and emergence in Arabidopsis thaliana. Plant J. 55: 335-347.

Kendrick MD and Chang C (2008). Ethylene signaling: new levels of complexity and regulation. Curr. Opin. Plant Biol. 11: 479-485.

Kępczyńska E, Ruduś I and Kępczyński J (2009). Endogenous ethylene in indirect somatic embryogenesis of Medicago sativa L. Plant Growth Regul. 59: 63-73.

Kong L and Yeung EC (1994). Effects of ethylene and ethylene inhibitors on white spruce somatic embryo maturation. Plant Sci. 104: 71-80.

Kumar V, Ramakrishna A and Ravishankar GA (2007). Influence of different ethylene inhibitors on somatic embryogenesis and secondary embryogenesis from Coffea canephora P ex Fr. Vitro Cell. Dev. Biol. Plant 43: 602-607.

Leclercq J, Adams-Phillips LC, Zegzouti H, Jones B, et al. (2002). LeCTR1, a tomato CTR1-like gene, demonstrates ethylene signaling ability in Arabidopsis and novel expression patterns in tomato. Plant Physiol. 130: 1132-1142.

Lin YH, Chang C and Chang WC (2000). Plant regeneration from callus culture of a Paphiopedilum hybrid. Plant Cell Tissue Organ Cult. 62: 21-25.

Litz RE and Yurgalevitch C (1997). Effects of 1-aminocyclopropane-1-carboxylic acid, aminoethoxyvinylglycine, methylglyoxal bis-(guanylhydrazone) and dicyclohexylammonium sulfate on induction of embryogenic competence of mango nucellar explants. Plant Cell Tissue Organ Cult. 51: 171-176.

Lu J, Vahala J and Pappinen A (2011). Involvement of ethylene in somatic embryogenesis in Scots pine (Pinus sylvestris L.). Plant Cell Tissue Organ Cult. 107: 25-33.

Ma N, Tan H, Liu X, Xue J, et al. (2006). Transcriptional regulation of ethylene receptor and CTR genes involved in ethylene-induced flower opening in cut rose (Rosa hybrida) cv. Samantha. J. Exp. Bot. 57: 2763-2773.

Mandal AKA, Gupta SD and Chatterji AK (2001). Factors affecting somatic embryogenesis from cotyledonary explants of safflower. Biol. Plant 44: 503-507.

Mantiri FR, Kurdyukov S, Lohar DP, Sharopova N, et al. (2008). The transcription factor MtSERF1 of the ERF subfamily identified by transcriptional profiling is required for somatic embryogenesis induced by auxin plus cytokinin in Medicago truncatula. Plant Physiol. 146: 1622-1636.

Martelli G, Greco I, Mezzetti B and Rosati P (1993). Isozymic analysis of somaclonal variation among renegerants from apple rootstock leaf tissue. Acta Hortic. 336: 381-388.

Murashige T and Skoog F (1962). A revised medium for rapid growth and bio assays with tobacco tissue cultures. Physiol. Plant 15: 473-497.

Nameth B, Dinka SJ, Chatfield SP, Morris A, et al. (2013). The shoot regeneration capacity of excised Arabidopsis cotyledons is established during the initial hours after injury and is modulated by a complex genetic network of light signalling. Plant Cell Environ. 36: 68-86.

Nayak NR, Sahoo S, Patnaik S and Rath SP (2002). Establishment of thin cross section (TCS) culture method for rapid micropropagation of Cymbidium aloifolium (L.) Sw. and Dendrobium nobile Lindl. (Orchidaceae). Sci. Horti. 94: 107-116.

Nissen P (1994). Stimulation of somatic embryogenesis in carrot by ethylene: Effects of modulators of ethylene biosynthesis and action. Physiol. Plant 92: 397-403.

Park SY, Murthy HN and Paek KY (2002). Rapid propagation of Phalaenopsis from floral stalk-derived leaves. Vitro Cell. Dev. Biol. Plant 38: 168-172.

Sakai S and Imaseki H (1971). Auxin-induced ethylene production by mung bean hypocotyl segments. Plant Cell Physiol. 12: 349-359.

Strader LC, Beisner ER and Bartel B (2009). Silver ions increase auxin efflux independently of effects on ethylene response. Plant Cell 21: 3585-3590.

Tieman DM, Ciardi JA, Taylor MG and Klee HJ (2001). Members of the tomato LeEIL (EIN3-like) gene family are functionally redundant and regulate ethylene responses throughout plant development. Plant J. 26: 47-58.

Tokuhara K and Mii M (2001). Induction of embryogenic callus and cell suspension culture from shoot tips excised from flower stalk buds of Phalaenopsis (Orchidaceae). Vitro Cell. Dev. Biol. Plant 37: 457-461.

Tyagi N and Dahleen LS (2011). Short term ethylene manipulation influences regeneration in Barley. J. Plant Mol. Biol. Biotechnol. 2: 65-73.

Young PS, Murthy HN and Yoeup PK (2000). Mass multiplication of protocorm-like bodies using bioreactor system and subsequent plant regeneration in Phalaenopsis. Plant Cell Tiss. Organ Cult. 63: 67-72. 